UDC 631.523:635.25(479.24)

LBC 41.31(5Азе)

\title{
APPEARANCE OF HETEROSIS IN ONION HYBRIDS OBTAINED ON STERILE BASIS APPLICATED TO CONDITIONS OF AZERBAIJAN
}

\author{
Sabir R. Hasanov
}

Genetic Resources Institute of Azerbaijan National Academy of Sciences, Baku, Azerbaijan Republic

\section{Chimnaz T. Namazova}

Genetic Resources Institute of Azerbaijan National Academy of Sciences, Baku, Azerbaijan Republic

\section{Zumrud A. Abbaszadeh}

Genetic Resources Institute of Azerbaijan National Academy of Sciences, Baku, Azerbaijan Republic

\begin{abstract}
The main goal of the study was to obtain hybrids having a heterositic effect using sterile lines of onions (Allium cepa L.) applicated to conditions of Azerbaijan. We used to study a valuable source material from the collection of the National Gene Bank of Azerbaijan. As a result of the combining ability evaluation of the sterile line and the pollinator, the most promising combinations (Arzamas S- $1 \times$ Hachmaz Mest, Luganskiy S- $2 \times$ Dusti, Arzamas S- $2 \times$ Ordubad-2, Luganskiy S- $1 \times$ Kaba, Arzamas S- $2 \times$ Sabir) were revealed the greatest heterosis efficiency of yield and shelf life quality were selected. The yield of hybrids obtained with the participation of varieties of Arzamas S-1 and Arzamas S-2 and paternal varieties, compared with the Strigunovsky variety, is 17.0$78.0 \%$ higher on average for all the years of testing. The study of the keeping capacity of $F_{1}$ hybrids showed that almost all of them have a higher keeping capacity than the original varieties. The keeping capacity of hybrids especially increases, the initial varieties of which do not have long-term storage sustainability. So, bulbs of varieties Dustu, Peshpazak, Sabir, Khachmaz mestniy, Ordubad-1 for 180-200 days of storage remained only 26-29 \%. Hybrids, obtained with the participation of these varieties; by the end of the study period, the keeping capacity remained at 49.8-88.7 \%, i.e. 1.9-3.1 times better. Many $F_{1}$ hybrids perform heterosis and early maturation, the combinations Arzamas S- $2 \times$ Strigunovsky, Arzamas S- $2 \times$ Dusti, Arzamas S- $1 \times$ Strigunovsky, Lugansky S- $2 \times$ Vostochny, Lugansky S- $2 \times$ Dusti, Arzamas S- $1 \times$ Khachmaz mestniy, Luganskiy S- $1 \times$ Kabo were more early matured than the standard for 14-18 days.

Key words: cytoplasmic male sterility, hybrids, heterosis, yield, sterile line.
\end{abstract}

УДК 631.523:635.25(479.24)

ББК $41.31(5 \mathrm{~A} 3 \mathrm{e})$

ПРОЯВЛЕНИЕ ГЕТЕРОЗИСА У ГИБРИДОВ РЕПЧАТОГО ЛУКА, ПОЛУЧЕННЫХ НА СТЕРИЛЬНОЙ ОСНОВЕ В УСЛОВИЯХ АЗЕРБАЙДЖАНА

\section{Сабир Рамазанович Гасанов}

Институт генетических ресурсов Национальной академии наук Азербайджана, г. Баку, Республика Азербайджан

\section{Чимназ Тофиковна Намазова}

Институт генетических ресурсов Национальной академии наук Азербайджана, г. Баку, Республика Азербайджан

\section{Зумруд Амиркулиевна Абасзаде}

Институт генетических ресурсов Национальной академии наук Азербайджана, г. Баку, Республика Азербайджан 
Аннотация. Основной целью исследования было создание гибридов, имеющих геторозисный эффект с использованием стерильных линий репчатого лука (Allium cepa L.) в условиях Азербайджана. К исследованию был привлечен ценный исходный материал из коллекции Национального Генбанка Азербайджана. В peзультате оценки комбинационной способности стерильной линии и опылителя были отобраны наиболее перспективные комбинации (Арзамас S-1 × Хачмазский Местный, Луганский S-2 × Дусти, Арзамас S-2 × Ордубад-2, Луганский S-1 × Каба, Арзамас S-2 × Сабир), дающие наибольший гетерозисный эффект урожайности и лежкости. Урожай гибридов, полученных с участием линий сортов Арзамас S-1, Арзамас S-2 и отцовских сортов, по сравнению с сортом Стригуновский на 17,0-78,0 \% выше за все годы испытаний. Изучение лежкости гибридов $F_{1}$ показало, что почти все они отличаются более высокой лежкостью, чем исходные сорта. Особенно повышается лежкость у гибридов, исходные сорта которых не выдерживают длительного хранения. Так, луковицы сортов Дусту, Пешпазак, Сабир, Хачмазский местный, Ордубад-1 за 180200 дней хранения сохранялись всего на 26-29\%. Гибриды же получение с участием этих сортов, к концу периода изучения на лежкость сохранялись на $49,8-88,7 \%$, то есть в 1,9-3,1 раза лучше. Многие гибриды $F_{1}$ проявляют гетерозис и по скороспелости, причем комбинации Арзамас S-2 $\times$ Стригуновский, Арзамас S-2 $\times$ Дусти, Арзамас S- $1 \times$ Стригуновский, Луганский S-2 × Восточный, Луганский S- $2 \times$ Дусти, Арзамас S-1 × Хачмазский местный, Луганский S- 1 К Кабо оказались в среднем более скороспелыми, чем стандарт на 1418 дней.

Ключевые слова: цитоплазматическая мужская стерильность, гибрид, гетерозис, урожайность, стерильная линия.

Введение. В овощеводстве большое внимание уделяется получению гетерозисных гибридных семян с использованием цитоплазматической мужской стерильности (ЦМС). К настоящему времени во многих странах достигнуты наибольшие практические результаты по ее использованию для получения гетерозисных гибридных семян $[8 ; 10-12 ; 15]$. Некоторые ученые, исследуя гибриды, созданные на стерильной основе, указывали, что на проявление стерильности у репчатого лука сильное влияние оказывают погодные условия года и географическое место выращивания $[9 ; 13 ; 14]$.

Исследователи сообщают, что источники ЦМС можно обнаружить почти у каждого сорта лука, но сохранить и закрепить признак ЦМС в потомстве оказывается труднее, чем обнаружить его [5-7].

Для получения гибридных семян в производственных условиях необходима стерильная линия, которая опылялась бы сортами обеспечивающими гетерозис по тому или иному хозяйственно важному признаку. Одновременно с селекционной работой по созданию стерильных линий следует проводить подбор пар для наиболее эффективных гетерозисных комбинаций в различных зонах [1-3].

Целью нашего исследования было изучение цитоплазматической мужской стерильности и создание перспективных гибридов с использованием стерильных линий местных и интродуцированных сортов репчатого лука в условиях Азербайджана.

Материалы и методы исследования. Исследования проводились на Апшеронской опытной базе Института генетических ресурсов Национальной академии наук Азербайджана в условиях интенсивного и регулярного орошения. В исследовании был использован ценный исходный материал из коллекции Национального Генбанка Азербайджана. Вся проделанная работа с ЦМС у репчатого лука может быть условно разделена на три основных этапа. На первом этапе из посаженных сортов лука были отобраны стерильные растения, с которых в дальнейшем собирались семена, полученные в результате свободного опыления. При этом учитывали и опыт работы исследователей по созданию стерильных линий, и методы получения гибридов репчатого лука на стерильной основе [1]. На втором этапе (закрепление стерильности) часть стерильных растений, полученных от гибридных семян, опыляли вручную пыльцой фертильных растений материнской формы. Другую часть оставляли для свободного опыления. Во время ежегодных прочисток линий удаляли все растения, которые могли быть заподозрены в наличии у них фертильности. Этот этап может продолжаться в течение нескольких поколений до достижения требуемого качества. Одновременно оценивали комбинационную способность стерильной линии, линии 
закрепителя стерильности и сортов-опылителей. Семена, собранные с растения сорта, обладающего высокой комбинационной способностью, служили основой для создания линии-опылителя. На следующем, третьем этапе более тщательно оценивали комбинационную способность стерильной линии и линииопылителя и отбирали наиболее перспективные образцы. В результате агробиологической оценки выделялись перспективные образцы и на их основе создавались стерильные линии.

Скрещивание проводили на изолированных участках и на одном массиве, без пространственной изоляции. Применяли метод изоляции растений гибридной пары под общим каркасным изолятором, покрытым капроновой сеткой или марлей. Полученные семена высевали в гибридный питомник первого поколения. Площадь посевной делянки составляла 2 м $^{2}$. Анализ гибридов $F_{1}$ в предварительном испытании проводился по стандартной методике изучения коллекции лука. Во всех случаях растения выращивались на площади питания 7-10 см. Математическая обработка данных проводилась по методике Б.А. Доспехова [4].

Вся проделанная работа с ЦМС репчатого лука условно разделена на два этапа:
1) изучения проявления ЦМС, создание линий с мужской стерильностью; 2) получение и сравнительное изучение гибридов $F_{1}$ на стерильной основе.

Результаты исследования и их обсуждение. У всех проанализированных сортов лука были обнаружены растения с мужской стерильностью. Пользуясь разработанной схемой закрепления мужской стерильности у репчатого лука, на опытном участке Института генетических ресурсов Азербайджана было создано более 15 стерильных линий. В настоящее время поддерживается и изучается 10 таких линий 8 сортов. Создано и включено в сравнительное изучение 10 гибридов $F_{1}$. Необходимо отметить, что у большинства изучавшихся нами гибридов в $F_{1}$ проявлялось доминирование признаков и свойств материнской линии, в частности признаков и свойств сортов острого и полуострого вкуса. У гибридов уменьшалась толщина чешуи (табл. 1).

Многие гибридные комбинации изучались в течение 2-3 лет. С 2017 г. было получено достаточное количество семян нескольких комбинаций, что позволило приступить к сравнительному изучению их на делянках с учетной площадью не менее 4 м ${ }^{2}$ и в 3-кратной повторности.

Таблича 1

\section{Некоторые морфологические признаки \\ наиболее перспективных гибридных комбинаций и родительских сортов лука}

\begin{tabular}{|c|c|c|c|c|c|}
\hline \multirow[t]{2}{*}{ Сорт, гибридная комбинация } & \multicolumn{2}{|c|}{ Окраска чешуи } & \multirow[t]{2}{*}{ Вкус } & \multicolumn{2}{|c|}{ Сочные чешуи } \\
\hline & внешние & внутренние & & число & толщина, мм \\
\hline «Каба» (стандарт) & желтая & белая & полуострый & 9,0 & 4,6 \\
\hline «Стригунов» (стандарт) & желтая & белая & острый & 7,0 & 3,6 \\
\hline 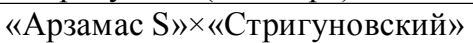 & желтая & белая & острый & 7,3 & 2,7 \\
\hline «Арзамас S-1»×«Ордубад-1» & желтая & белая & полуострый & 7,1 & 3,0 \\
\hline «Арзамас S-1»×«Каба» & желтая & белая & полуострый & 8,0 & 3,4 \\
\hline «Арзамас»×«Стригуновский» & желтая & белая & острый & 8,4 & 3,2 \\
\hline «Арзамас S-1»×«Ордубад-2» & красная & белая & полуострый & 8,5 & 3,1 \\
\hline $\begin{array}{l}\text { «Арзамас S-1»×«Масаллинский } \\
\text { местный» }\end{array}$ & красная & белая & полуострый & 7,0 & 3,1 \\
\hline $\begin{array}{l}\text { «Арзамас S-1»×«Хачмазский } \\
\text { местный» }\end{array}$ & красная & белая & полуострый & 6,8 & 3,1 \\
\hline «Арзамас S-2»×«Ордубад-1» & белая & белая & полуострый & 8,0 & 3,0 \\
\hline «Хачмазский местный» & желтая & белая & полуострый & 9,2 & 3,7 \\
\hline «Ордубад-1» & белая & белая & полуострый & 8,3 & 3,8 \\
\hline «Ордубад-2» & красная & $\begin{array}{l}\text { фиолетово- } \\
\text { синяя }\end{array}$ & полуострый & 8,0 & 3,8 \\
\hline «Масаллинский местный» & красная & $\begin{array}{c}\text { фиолетово- } \\
\text { синяя }\end{array}$ & полуострый & 7,5 & 4,2 \\
\hline
\end{tabular}


По данным предварительного испытания гибридов $F_{1}$ в сравнении с родительскими сортами было установлено, что большинство гибридных комбинаций урожайнее родителей, т.е. проявился гетерозисный эффект по урожайности. По урожайности гибриды сравнивали со стандартными сортами Каба и Стригуновский, интродуцированными в аналогичных условиях. В результате проведенного анализа выделились гибридные комбинации, значительно превышающие по урожайности, как исходные сорта, так и стандартные (табл. 2).

В таблице 2 приводится список наиболее перспективных гибридов $F_{1}$, полученных на стерильной основе. Как видно из таблицы, урожай гибридов, полученных с участием линий сортов Арзамас S-1, Арзамас S-2 и отцовских сортов, по сравнению с сортом (Стригуновский) на 17,0-78,0 \% выше в среднем за все годы испытания. Особенно выделяются в этом отношении комбинации: Луганский S-2 × Дусти, Арзамас S-1 × Масаллинский местный, AрзамасS-1 × Стригуновский, Стригуновский S- $1 \times$ Сабир и др.

Многие гибриды $F_{1}$ проявляют гетерозис и по скороспелости, причем комбинации Арзамас S-2 × Стригуновский, Арзамас S-2 $\times$ Дусти, Арзамас S-1 × Стригуновский, Луган- ский S-2 × Восточный, Луганский S-2×Дусти, Арзамас S-1 × Хачмазский местный, Луганский S-1 × Каба оказались в среднем более скороспелыми, чем стандарт на 14-18 дней.

Обращают на себя внимание комбинации Арзамас S-1 × Каба, Луганский S-1 × Каба. По урожайности они близки к стандартному сорту Каба или незначительно его превышают. Если же иметь в виду, что сорт Каба один из наиболее урожайных сортов, а материнской линией являются сорта Арзамас и Луганский с более низкой урожайностью, то и в этом случае обнаруживается гетерозис. Кроме того, отмеченные комбинации отличаются лежкостью и скороспелостью (табл. 3).

Изучение лежкости гибридов $F_{1}$ показало, что почти все они отличаются более высокой лежкостью, чем исходные сорта (табл. 3). Особенно повышается лежкость у гибридов, исходные сорта которых не выдерживают длительного хранения. Так, луковицы сортов Дусту, Пешпазак, Сабир, Хачмазский местный, Ордубад-1 за 180-200 дней хранения сохранялись всего на 26-29 \%. Гибриды же полученные с участием этих сортов, к концу периода изучения на лежкость сохранялись на 49,8$88,7 \%$, то есть в $1,9-3,1$ раза лучше. Мы считаем, что еще не использованы все возможно-

Характеристика урожайности наиболее перспективных гибридов $F_{1}$,

Таблииа 2 полученных на основе ЦМС

\begin{tabular}{|c|c|c|c|c|}
\hline \multirow[b]{3}{*}{ Гибридная комбинация } & \multicolumn{4}{|c|}{ В среднем 3 года } \\
\hline & \multicolumn{2}{|c|}{ Урожайность, \% } & \multirow[t]{2}{*}{ Товарность, \% } & \multirow{2}{*}{$\begin{array}{c}\text { Период } \\
\text { вегетации } \\
\text { (дней) }\end{array}$} \\
\hline & к стандарту & $\begin{array}{l}\text { к наиболее } \\
\text { урожайному } \\
\text { родителю }\end{array}$ & & \\
\hline «Стригуновский» (стандарт) & 100,0 & - & 88,4 & 125 \\
\hline «Арзамас S-2» $\times$ «Стригуновский» & 123,1 & 123,1 & 96,5 & 107 \\
\hline «Арзамас S-2» × «Ордубад-2» & 155,0 & - & 97,7 & 112 \\
\hline «Арзамас S-2» × «Дусти» & 134,8 & - & 96,5 & 108 \\
\hline $\begin{array}{l}\text { «Арзамас S-1» × «Масаллинский } \\
\text { местный» }\end{array}$ & 172,1 & 111,0 & 96,1 & 113 \\
\hline «Арзамас S-1» × «Стригуновский» & 161,4 & 111,7 & 96,4 & 110 \\
\hline «Стригуновский S-1» × «Сабир» & 159,4 & 91,7 & 92,6 & 122 \\
\hline «Стригуновский S-1» × «Пешпазак» & 145,4 & - & 93,0 & 122 \\
\hline «Луганский S-2» × «Дусти» & 178,3 & 151,2 & 97,8 & 111 \\
\hline «Луганский S-2» × «Стригуновский» & 117,0 & 95,7 & 93,7 & 110 \\
\hline «Стригуновский S-1» × «Ордубад-2» & 154,3 & 135,4 & 96,5 & 112 \\
\hline «Каба» & 176,2 & - & 92,0 & 132 \\
\hline «Арзамас S-1» × «Хачмазский местный» & 99,2 & 128,0 & 98,4 & 111 \\
\hline «Арзамас S-1» × «Каба» & 105,2 & 105,2 & 95,8 & 122 \\
\hline «Луганский S-1» × «Каба» & 121,4 & 116,0 & 94,6 & 111 \\
\hline
\end{tabular}


сти создания гетерозисных гибридов лука на основе ЦМС. Интересным, на наш взгляд, является сравнение урожайности гибридных комбинаций на стерильной и фертильной основе с участием одних и тех же сортов.

Так, гибриды с участием сорта Арзамас на основе обеих стерильных линий были урожайнее тех же комбинаций, полученных на фертильной основе. В то же время у 6 комбинаций из 8 с использованием сорта Луганский, большей урожайностью отличались комбинации, полученные на фертильной основе.

Урожайность комбинаций, полученных на фертильной основе, не должна быть выше урожайности комбинаций на основе ЦМС, так как в первом случае гибридность не превышает $50 \%$, а во втором она близка к $100 \%$. Такое положение можно объяснить тем, что в данном случае линия с мужской стерильностью обладает низкой комбинационной способностью. Проявление же гетерозисного эффекта в комбинациях, полученных на фертильной основе, говорит о том, что в сортовой популяции имеются потенциальные возможности выделения линий с высокой комбинационной способностью.

На основании данных полученных при создании гетерозисных гибридов лука, рекомендуем создавать гомозиготные линии в большом количестве по каждому интересующему сорту и оценивать их на комбинационную способность.
Выводы. Сравнительное изучение гибридов, полученных на основе ЦМС, позволило выделить ряд комбинаций, значительно превышающих как исходные, так и стандартные сорта по урожайности, скороспелости и лежкости. Установлено, что разные линии с мужской стерильностью обладают различной комбинационной способностью. У гибридов $F_{1}$ лука, полученных на стерильной основе, проявляется доминирование признаков сортов острого типа, а так же значительно повышается лежкость.

\section{СПИСОК ЛИТЕРАТУРЫ}

1. Анципович, В. В. Гетерозисная селекция лука репчатого с использованием ЦМС / В. В. Анципович, Н. П. Куприенко // Картофель и овощи. 2006. - № 8. - С. 29.

2. Гасанов, С. Р . Изучение цитоплазматической мужской стерильности репчатого лука в условиях Азербайджана / С. Р. Гасанов, Г. А. Гусейнзаде // Международный журнал прикладных и фундаментальных исследований. - 2017. - № 6. C. 262-265.

3. Гасанов, С. Р. Исследование ядерно-цитоплазматической мужской стерильности у некоторых местных сортов репчатого лука (Allium сера L.) Азербайджана / С. Р. Гасанов // Труды Института генетических ресурсов НАНА - Баку. - 2009. C. $375-379$.

4. Доспехов, Б. А. Методика полевого опыта (с основами статистической обработки результатов

Таблииа 3

Лежкость гибридов лука полученных на стерильной основе (в среднем за 2016-2018 гг., продолжительность хранения 180-200 дней)

\begin{tabular}{|l|c|c|}
\hline \multicolumn{1}{|c|}{ Гибриды и родительские сорта } & Хранение луковиц (дни) & $\begin{array}{c}\text { Сохранившиеся } \\
\text { луковицы, \% }\end{array}$ \\
\hline «Каба» (стандарт) & 213 & 47,4 \\
\hline «Арзамас S-1» × «Каба» & 276 & 68,2 \\
\hline «Луганский S-1» ×«Каба» & 200 & 73,0 \\
\hline «Ордубад-1» & 240 & 26,1 \\
\hline «Луганский S-1» × «Ордубад-1» & 300 & 70,5 \\
\hline «Ордубад-1 S-1» × «Кабо» & 250 & 61,0 \\
\hline «Ордубад-1 S-1» × «Дусту» & 250 & 68,0 \\
\hline «Дусту» & 200 & 26,0 \\
\hline «Арзамас S-2» × «Сабир» & 212 & 68,7 \\
\hline «Сабир» & 166 & 27,6 \\
\hline «Арзамас S-2»×«Пешпазак» & 170 & 49,8 \\
\hline «Пешпазак» & 180 & 28,5 \\
\hline $\begin{array}{l}\text { «Арзамас S-1» × «Хачмазский } \\
\text { местный» }\end{array}$ & 250 & 88,7 \\
\hline «Хачмазский местный» & 200 & 29,0 \\
\hline
\end{tabular}


исследований) / Б. А. Доспехов - М. : Книга по Требованию, 2012. -352 с.

5. Концевая, И. Совершенствование методики биотестирования на основе Allium-теста / И. Концевая, Т. Толкачева // Веснік Віцебскага дзяржаўнага ўніверсітэта. - 2012. - № 6 (72). - С. 57-65.

6. Пивоваров, В. Ф. Овощи России / В. Ф. Пивоваров - М. : ГНУ ВНИИССОК, 2006. - 384 с.

7. Тико, Е. А. Сортоиспытание раннеспелых гибридов $F_{1}$ лука репчатого в северокавказском регионе / Е. А. Тико // Плодоводство и виноградарство Юга России. - 2016. - № 39 (03). - С. 3-11.

8. Becerra, D. C. Age and physiological condition of donor plants affect in vitro morphogenesis in leaf explants of Passiflora edulis f. flavicarpa / D. C. Becerra, A. P. Forero, G. A. Góngora // Plant Cell Tissue Organ Culture. 2004. - Vol. 79. - P. 87-90.

9. Breeding and molecular biology progress of male sterile pepper in China / L. Liu, X. R. Li, G. H. Wang, D. C. Wang // Current Biotechnol. 2011. - Vol. 1. - P. 254-259.

10. Budar, F. The nucleo-mitochondrial conflict in cytoplasmic male sterilities revisited / F. Budar, P. Touzet, R. De Paepe// Genetica. - 2003. - Vol. 117. P. 3-16.

11. Cebeci, E. Male Sterility Application in Allimus / E. Cebeci // TABAD. - 2014. - Vol. 7 (2). - P. 37-40.

12. Inden, H. Japanese bunching onion (Allium fistulosum L.) / H. Inden, T. Asahira // Onion and allied crops / ed. by H. D. Rabinowitch, J. L. Brewster. - Boca Raton, Florida, 1990. - № 3. - P. 159-178.

13. Shukla S. A review on the scope for increasing in vitro production of pomegranate (Punica Granatum 1.) cultivars and its application in the human health sector with emphasis on the Indian industry / S. Shukla, T. Raman, K. Shukla // Plant Cell Biotechnology and Molecular Biology. - 2016. Vol. 16. - P. 60-73.

14. Two RAPD markers linked to a major fertility restorer gene in pepper / B. X. Zhang, S. W. Huang, G. M. Yang, J. Z. Guo // Euphytica. - 2000. - Vol. 113. P. 155-161.

15. Yamashita, K. Possibility of developing male sterile line of shallot (A. cepa L. Agregatum group) with cytoplasm from A. galanthum Kar. Et Kir. / K. Yamashita, T. Tashiro // Journal of the Japanese Society for Horticultural Science. - 1999. № 68. - P. 256-262.

\section{REFERENCES}

1. Antsipovich V.V., Kuprienko N.P. Geterozisnaya selektsiya luka repchatogo $\mathrm{s}$ ispolzovaniem TsMS [Heterosis Selection of Onions Using CMC]. Kartofel $i$ ovoshchi [Potatoes and Vegetables], 2006, no. 8, p. 29.
2. Hasanov S.R., Guseynadze G.A. Izuchenie tsitoplazmaticheskoy sterilnosti luka repchatogo $\mathrm{V}$ Azerbaydzhana [Study of Cytoplasmic Male Sterility of Onions in Azerbaijan]. Mezhdunarodnyy zhurnal prikladnykh $i$ fundamentalnykh issledovaniy [International Journal of Applied and Basic Research], 2017, no. 6, pp. 262-265.

3. Hasanov S.R. Issledovanie yadernotsitoplazmaticheskoy muzhskoy sterilnosty u nekotorykh mestnyhk sortov repchatogo luka (Allium cepa L.) Azerbaydzhana [Investigation of Nuclear Cytoplasmic Male Sterility in Some Local Varieties of Onions (Allium cepa L.) in Azerbaijan]. Trudy Instituta geneticheskikh resursov NANA [Transactions of the ANAS Institute of Genetic Resources - Baku], 2009, pp. 375-379.

4. Dospekhov B.A. Metodika polevogo opyta (s osnovami statisticheskoy obrabotki rezultatov issledivaniy) [Methods of Field Experience (With the Basics of Statistical Processing of Rsearch Results)]. Moscow, Kniga po Trebovaniyu Publ., 2012. 352 p.

5. Kontsevaya I., Tolkacheva T. Sovershenstvovanie metodiki biotestirovaniya na osnove Allium-testa [Perfecting the Method of Biotesting Based on AlliumTest]. Vesnik Vicebskaga dzyarzhay̆naga ÿniversiteta [Bulletin of the Vitebsk State University], 2012, no. 6(72), pp. 57-65.

6. Pivovarov V.F. Ovoshchi Rossii [Vegetables of Russia]. Moscow, GNUVNIISSOK Publ., 2006. 384 p.

7. Tiko E.A. Sortoispytanie rannespelykh gibridov $F_{1}$ luka repchatogo v severokavkazskom regione [Variety Testing of Early Maturing $F_{1}$ Hybrids of Bulb Onion in the North Caucasus Region]. Plodovodstvo $i$ vinogradarstvo Yuga Rossii [Fruit Growing and Viticulture in the South of Russia], 2016, no. 39 (03), pp. 3-11.

8. Becerra D.C., Forero A.P., Góngora G.A. Age and Physiological Condition of Donor Plants Affect in Vitro Morphogenesis in Leaf Explants of Passiflora Edulisf. flavicarpa. Plant Cell Tissue Organ Culture, 2004, vol. 79, pp. 87-90.

9. Liu L., Li X.R., Wang G.H., Wang D.C. Breeding and molecular biology progress of male sterile pepper in China. Current Biotechnol, 2011, vol. 1, pp. 254-259.

10. Budar F., Touzet P., Paepe R. De The NucleoMitochondrial Conflict in Cytoplasmic Male Sterilities Revisited, Genetica, 2003, vol. 117, pp. 3-16.

11. Cebeci E. Male Sterility Application in Allimus. TABAD, 2014, vol. 7 (2), pp. 37-40.

12. Inden H., Asahira T. Japanese Bunching Onion (Allium fistulosum L.). Rabinowitch H.D., Brewster J.L., eds. Onion and Allied Crops, Boca Raton, Florida, 1990, no. 3, pp. 159-178.

13. Shukla S., Raman T., Shukla K. A. Review on the Scope for Increasing in Vitro Production of Pomegranate (Punica Granatum 1.) Cultivars and Its Application in the Human Health Sector with Emphasis 
on the Indian Industry. Plant Cell Biotechnology and Molecular Biology, 2016, vol. 16, pp. 60-73.

14. Zhang B.X., Huang S.W., Yang G.M., Guo J.Z. Two RAPD Markers Linked to a Major Fertility Restorer Gene in Pepper. Euphytica, 2000, vol. 113, pp. 155-161.
15. Yamashita K., Tashiro T. Possibility of developing male sterile line of shallot (A. cepa L. Agregatum group) with cytoplasm from A. galanthum Kar. Et Kir. Journal of the Japanese Society for Horticultural Science, 1999, no. 68, pp. 256-262.

\section{Information about the Authors}

Sabir R. Hasanov, Candidate of Sciences (Biology), Associate Professor, Head of the Department of Vegetable and Melon Plants, Genetic Resources Institute of Azerbaijan National Academy of Sciences, prosp. Azadlyg, 155, AZ1106 Baku, Azerbaijan Republic, Sabir_Hasanov@rambler.ru.

Chimnaz T. Namazova, Candidate of Sciences (Biology), Associate Professor, Senior Researcher, Genetic Resources Institute of Azerbaijan National Academy of Sciences, prosp. Azadlyg, 155, AZ1106 Baku, Azerbaijan Republic, 3imnaznamazova@rambler.ru.

Zumrud A. Abbaszadeh, Doctoral Student, Genetic Resources Institute of Azerbaijan National Academy of Sciences, prosp. Azadlyg, 155, AZ1106 Baku, Azerbaijan Republic, zumrudbaku@gmail.com.

\section{Информация об авторах}

Сабир Рамазанович Гасанов, кандидат биологический наук, доцент, заведующий отделом овощных и бахчевых культур, Институт генетических ресурсов Национальной академии наук Азербайджана, просп. Азадлыг, 155, AZ1106 г. Баку, Республика Азербайджан, Sabir_Hasanov@rambler.ru.

Чимназ Тофиковна Намазова, кандидат биологический наук, доцент, старший научный сотрудник, Институт генетических ресурсов Национальной академии наук Азербайджана, просп. Азадлыг, 155, AZ1106 г. Баку, Республика Азербайджан, 3imnaznamazova@rambler.ru.

Зумруд Амиркулиевна Абасзаде, докторант, Институт генетических ресурсов Национальной академии наук Азербайджана, просп. Азадлыг, 155, AZ1106 г. Баку, Республика Азербайджан, zumrudbaku@gmail.com. 